\title{
造幣寮の建築
}

\section{泉布観再考一 - -}

$\begin{array}{llll}\text { 正会員 木 } & \text { 村 寿 夫* } \\ \text { 正会員山 } & \text { 田 幸 } & \text { 一** }\end{array}$

\section{I. 序}

大阪造幣寮はいうまでもなく明治開国に伴い建設され た本邦最初の工場施設で，すでに諸先学による多くの論 考がある”。造幣寮の創業式は明治 4 年 2 月(1871 年 4 月) $)^{21}$ で，この頃には主要施設である金銀貸幣鋳造場・ 地金局 (本局) ・異人館・応接所 (泉布観) がほぼ完成 ${ }^{31} し$ ていた。しかし創建時の建物はほとんよ゙取り壊され, 現 在では泉布観と鋳造場の一部"が残っているだけである。

さて当寮の応接所として建築された泉布観は昭和 39 年に修理工事が完了し，その際詳しく調査された『重要 文化財泉布観修理工事報告書』(以下，単に・報告書』 と呼ぶ）が刊行されているが，今なお末解決の問題や若 干の矛盾点が残っているように思える。本稿では，まず 平面形状の推移をたよ゙り，かつそれに伴って変化したで あろう創建当初の立面状態をも併せて検討する。

\section{II. 『泉布観修理工事報告書』による現状と復原}

現在の泉布観は寄棟, 煉瓦造 2 階建, 瓦茸, タスカン 様式の円形断面を持つ石柱を並べた回廊で囲繞されたコ ロニアル様式の建物である。東側正面の柱廊は柱間が 7 間で構成され，その中央には 1 間突き出し切妻，瓦蒀の 車寄（玄関）が付く。南及び北側の柱廊は 5 間構成であ るが，次にみるように西側への増築のため北側の石柱の 間隔は南側に比べ大きくなっている。1・2 階の境には 木造の胴蛇腹が取り付けられ，その背後に束石を立て上 下の石柱を繫いでいる。なお屋根は外樋形式で，小屋組 は和小屋である。ところで『報告書』によれば，現状は 明治 26 年 11 月から同 28 年 1 月に加けて，北白河宮能 久親王が居住されたとき，西側部分が増築された（以下， 単に『増築後の泉布観』と呼ぶ）ためとして, 創建当初 の姿は次のようであったとしている。(写真 1 )

イ。車寄せは現状より小さかった。

口. 西側の 1 間通りは存在しなかった。

八. 北側柱廊も南側と対応する位置に柱が立てられ， 共に等間隔の 5 間構成であった。

* 関西大学 助手

** 関西大学 教授・工博 （昭和 57 年 12 月 2 日原稿受理日，討論期限昭和 58 年 12 月末日)
二、軒・胴蛇腹とも木造で, 軒回りにも木造のパラ ペットを設置した内樋形式であった。

木，屋根は瓦蒀で，和小屋であった。

III. 平面形状について

『報告書』の復原のうちこここでは，前章八の問題に 焦点を絞り検討を進めたい。

1. 平面復原に関する既往の説

創建泉布観の平面形状については，既に2つの復原考 祭がある。

（1）南・北柱間を 6 間とする説

林野全考博士に上れば創建時の泉布観は南・北柱間が 6 間であった ${ }^{5)}$ (以下, 単に『6 間の泉布観』之呼ぶ) とされ次のように説明されている。(写真 2$)$

『さてこうして見ると, 柱の数が減っているのも, そ の時減じたのではないかと推察される。これは痕跡から 解り難かったが, 現在北列が柱間 12.7 尺で, 南側が 11.5 尺で，正面が 9.95 尺である。正面の柱間は変っ ていないので，旧図面で柱間を出す之，約 9.6 尺となり 大体正面之合致する。また南及北洋人館の創建当初の平 面図は，いずれも正面之ほぼ同じで，若干狭いのみであ り(約 3.5 寸), しかも亴側主体壁の列で終っている。従っ

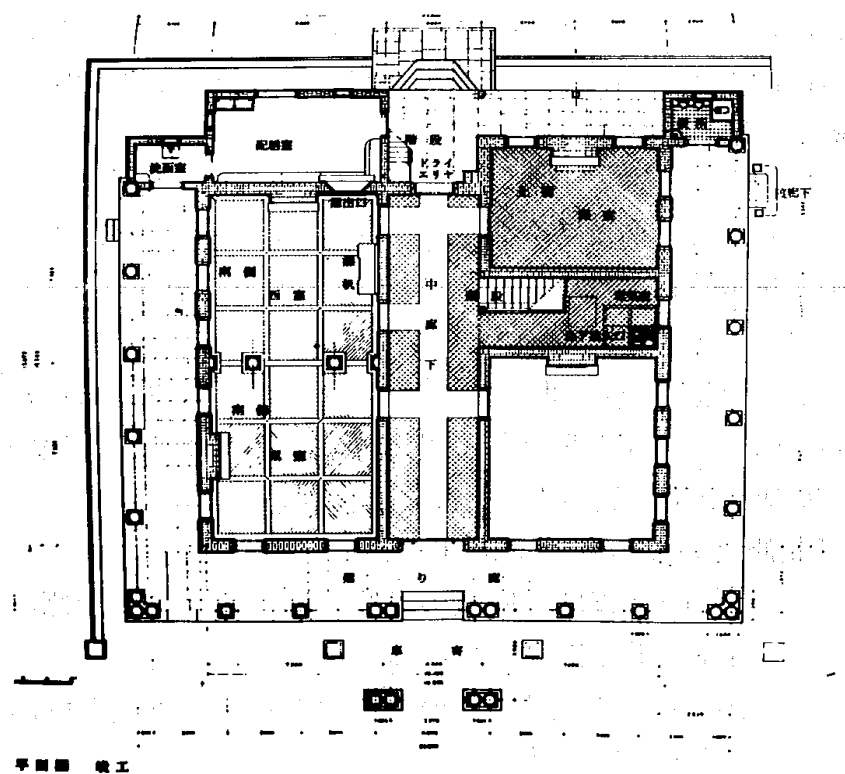

写真 1 『増築後の泉布観』（報告書』より） 


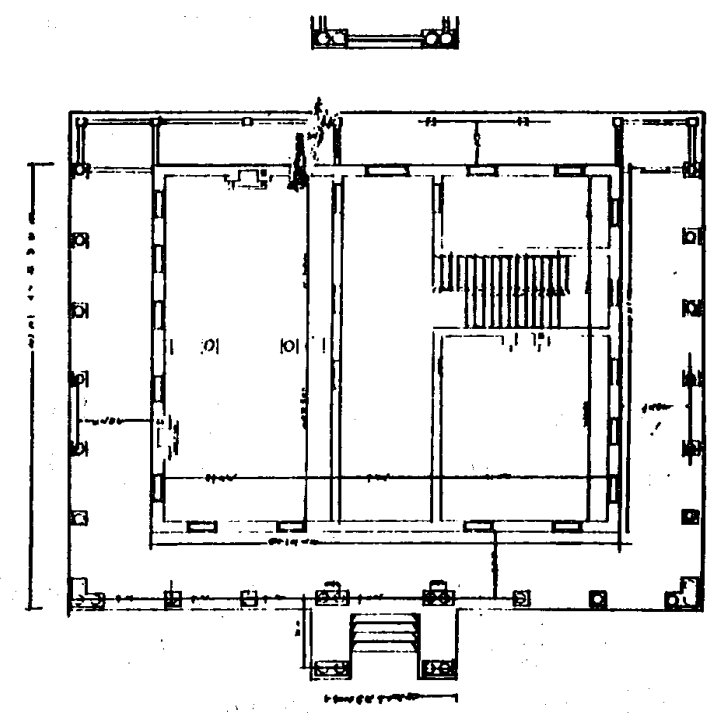

写真 2『6 間の泉布観』(中村論文上り)

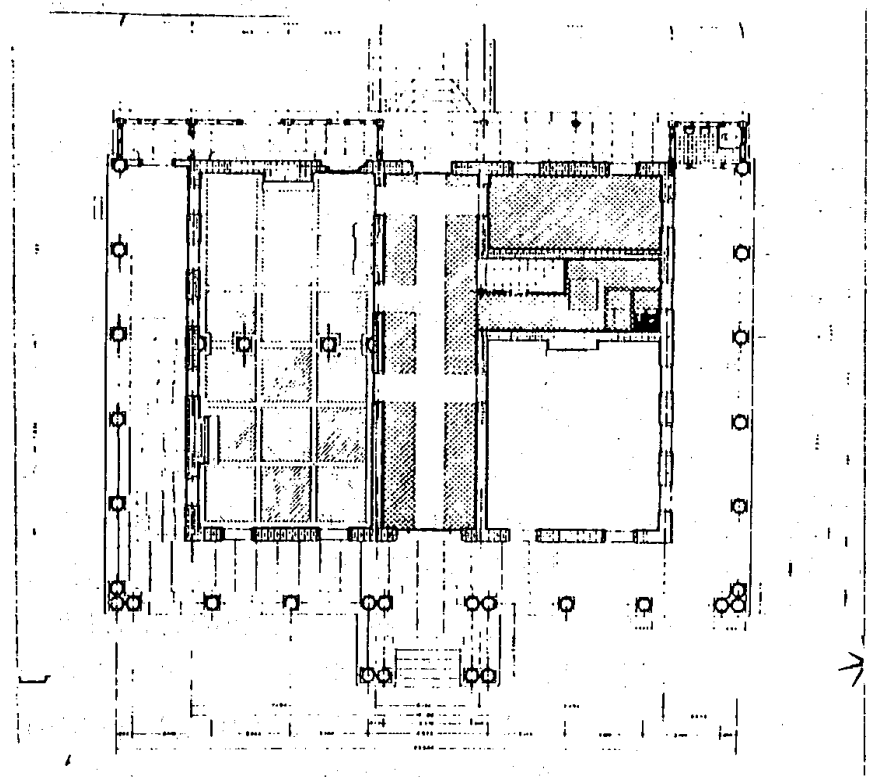

写真 $3 『 5$ 間の泉布観』(『報告書』より)

て泉布観も，もとは創建当時の図で見るごとくであり， 増築工事のとき南北一二階共 4 本の柱を何ら加の理由で 撤去したと推測する。』

ここで『その時』とは前述の北白河宮居住の時のこと で，すなわち改築の時期は，『報告書』と同じ理由(6で 明治 26 年 11 月か 5 明治 28 年 1 月の間とされている。

(2) 南・北柱間を 5 間とする説

『報告書』が南・北柱間を当初から 5 間構成であった (以下, 単に『5 間の泉布観』と呼ぶ）とする主な理由 は次のように記述されている。(写真 3 )

『北側の石柱の間隔は延びておる。

イ. 現状の基礎は, 煉瓦の品質, 積立工法とも南側の 石柱基礎と相違している。

口. 南側と同断位置 (3.484 m 間隔) に, 南側と同断 手法の基礎痕跡がある。

八. 胴蛇腹, 回り廊二階床組, 高欄部材はすべて後補
材一部転用材で構成されている。

二. 軒蛇腹, 軒天井, 回り廊小屋組部材も後補材一部 転用材で構成されている。尚古図では南北側共 6 間構成に記載されているが，基礎部調查において その痕跡がなく構内に石柱破片もない。』

以上のうちロは動かすことのできない重要な事奏で, これを以て『報告書』は創建時を『5 間の泉布観』であっ たとする確証を得たようで，そのために他の部分（立面 等) の復原の根拠の一部として使用している『古図』を, 列柱の数に限ってはニの後段で否定せざるを得なくなっ たと思われる。

2. 既往の説の資料

ここでは, 林野説が『旧図面』及び『創建当初の図』、『報 告書』が『古図』としている資料を検討する。

(1) 『6 間の泉布観』の資料

6 間説の根拠亡なる資料には次の 3 種類がある。

(1)明治 10 年付, 『行在につき往復其他参考文書』8

これは明治 10 年の天皇行幸に先がけて準備された公 文書の綴りで，ほ之んよ゙の文書に明治 9 年 12 月 20 日前 後の日付がある。この文書の中に天皇行在時の部屋の割 付図がある。この図は 2 枚の和紙 $(36 \mathrm{~cm} \times 36 \mathrm{~cm}, 36$ $\mathrm{cm} \times 64 \mathrm{~cm})$ に烏口で墨入れされた $1 / 100$ のもので, 泉 布観亡西側の附属建物まで詳しく描かれており，なお玉 座・侍従等の墨書も認められる。

この図では, 南・北柱間は明らかに 6 間に書き込まれ ており，西側の増築は行われていない。この文書がいわ ゆる公文書であること, 縮尺が $1 / 100$ と比較的に大きい こと等から，柱の本数に関する限りその信頼度はかなり 高いと考えられる。

(2)『造幣局大地図』

大阪造幣局には『造幣局大地図』 ${ }^{9)}$ と言う配置図があ り，ここでも泉布観は 6 間に描かれている。作画の年代 は記入されていないが，「造幣局百年史資料編』で明治 12 年 1 月起工, 同 12 年 11 月竣工となっている曹達製 造所が記入されていること，明治 15 年 10 月から同 16 年 11 月にかけて再築された地金局（本局）が再築前の 平面形状を示していることから，明治 13 年から同 15 年 の中頃までに描かれたものと考えたい。林野博士も明治 15 年前後のもの亡されている。

(3)中村角之助 ${ }^{10)}$ 『造幣局にいて』

『建築と社会』昭和 7 年 8 月号に発表された中村論文 には創建当初とする泉布観の図が揭載されており，ここ でも南・北柱間は 6 間となっている。この図には昭和 7 年の時点で創建時の図面を複写した旨の付記があるが, 元の図面についての十分な説明は行われていない。しか し，この点に関しては同時に掲載された鋳造場の図が現 存の『出来形絵図』 ${ }^{11}$ と全く同様であること, 及び、泉 布観正面控』の図はマンチニ ${ }^{12)}$ 筆のペン画、『Imperial 
Mint Osaka Japan』（1873 年 2 月 18 日）に非常によく 似ていることから，泉布観についても，やはり創建の図 面を複写したものと考えてよいだろう。

以上, (1), (2), (3)の何れも 6 間構成で, 少なくともマ ンチニ筆ペン画の時期から『造幣局大地図』の時期まで, すなわち明治 6 年 2 月から同 15 年頃まで，『6 間の泉布 観』が存在していたと考えざるを得ない。

\section{（2）『5 間の泉布観』の資料}

『現状の泉布観』になる以前に『報告書』にいう『5 間の泉布観』が存在したことは, ·前項の基礎部調査の結 果動かし難い。これを補足する 5 間の泉布観の図面 ${ }^{13)}$ が 大阪造幣局に 2 種ある。

(1)布引き紙に 1 ・2 階の平面が烏口で描かれたもの で，図中に『泉布観』と記人されている。これは非常に 粗い図面で煉瓦壁の部分には多くの訂正が書き込まれて

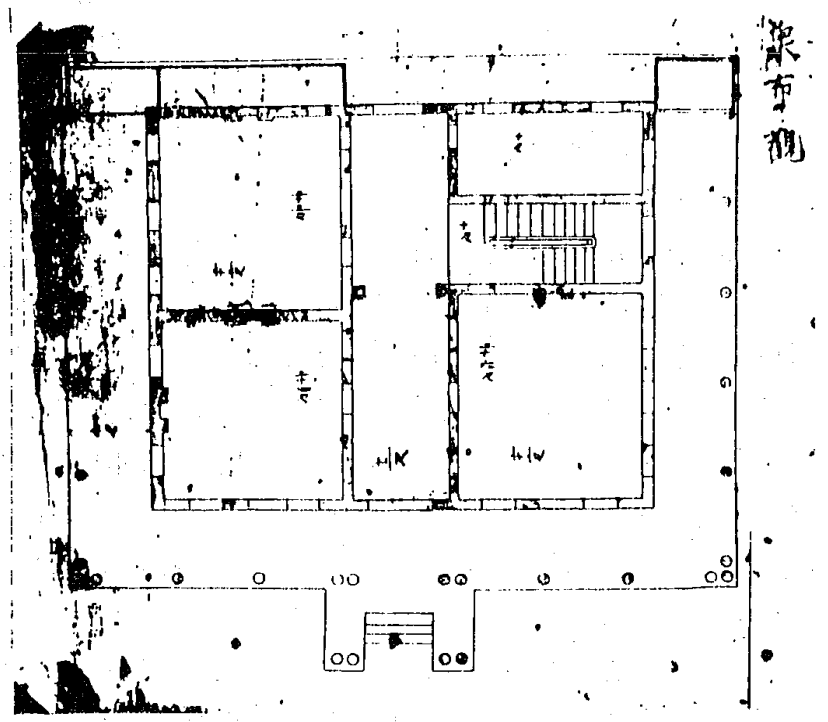

写真 45 間の図(1)

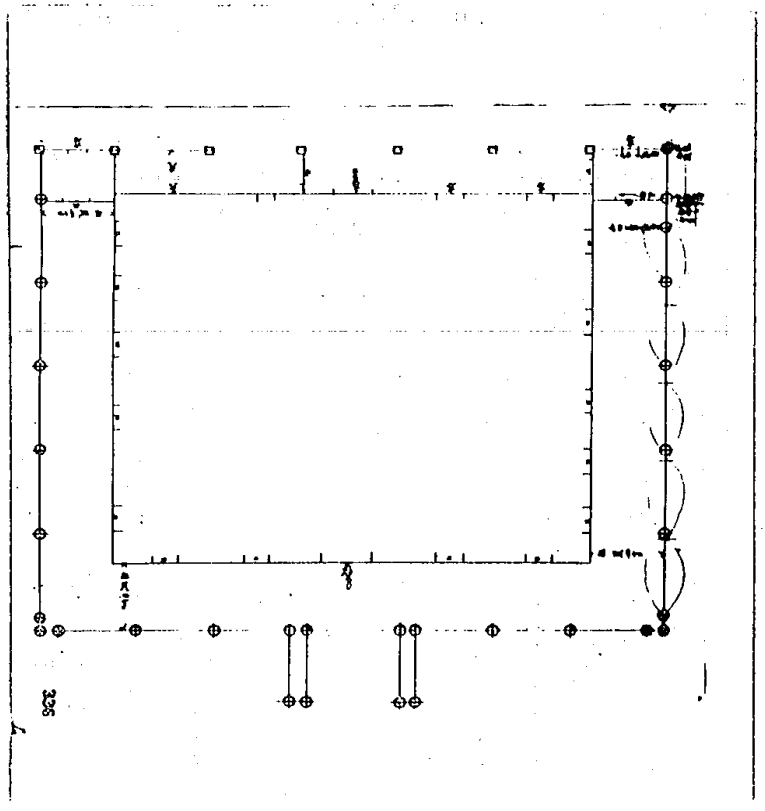

写真 5.5 間の図(2)
いる。しかし柱位置は明確に南北対応の5 間構成を示し ている。(写真 4$)$

(2)薄手の和紙に烏口と毛筆で描かれたもので，縮尺は 1/100である。この図には 1 階平面の回廊のみが描かれ ているが，柱位置は南北対応の 5 間構成を示している。 特に北側柱廊の石柱の表示は, 南側柱と対応する位置と, 正面の円柱真加ら裹面の角柱真（西側増築後の北側西室 の煉瓦軀体の壁真）までの桁行き全体を 6 等分した位置 之の両方にうたれている。この表現から，本図は西側増 築に先立ち北側の柱間を検討するために描かれたとする ことが最も妥当である。(写真 5 )

これら両図の作成された時期は不明であるが，相対的 に(1)は(2)より古く 5 間構成であった時のもので，(2) 5 間から現状の西側増築の状態に改築される時のものとす ることができる。また『 5 間の泉布観』から『増築後の 泉布観』に変更されたことは，後節に説明する転用材の 使用状況からも十分に説明が付く。

以上の資料を総合すると, 創建当初は『6 間の泉布観』 であったが，ある時期，南北の柱間が対応する 5 間構成 に一旦改築され，その後西側への増築に伴って北側の柱 間が変更され『増築の泉布観』になったと考えざるを得 ない。

\section{3. 工事時期の検討}

以上の考察から泉布観は創建後 2 度の増改築工事が行 われたと考えられるが，その具体的な時期を以下に検討 する。

\section{（1） 明治 16 年の工事記録}

次に示す『造幣局長第十年報書』 ${ }^{14)}$ は明治 16 年 7 月 1 日より同 17 年 6 月 30 日までの 1 ヶ年間の報告で, こ こに重要な文章がある。

『当局泉布観八造䌘局長住居卜外国来賓応接所卜ノ為二建設七 シモノニシテ明治五年車駕西巡ノ際行在所二充テラレ初メテ 泉布観ノ名称シ賜ハリ同十年再ビ行在所トナリ又内外貴賓， 応接所タリ然ル二其家屋タルヤ明治初年ノ建築二係り煉瓦石 造未熟ノ際ニシテ木石ノ接合緊固ナラザラル等ヨリ或八称斜 シ或八破ぎょくヨ生ジ加之周囲ノ木材悉ク腐朽シ亦傾倒ノ恐 ナキ能八ズ因テ外部ノ改築其他ノ修續二客年八月允許习得テ 着手シ当六月二至り落成セり』

この記述は公文書であることから十分に信頼がおけ る。修理工事の内容は文面に明記されていないが，しか し『傾倒ノ恐レナキ能ハズ』という表現から推して, 相 当大掛りなものであったことは疑いない。ともあれ明治 16 年 8 月から同 17 年 6 月までの 11 ケ月を要して工事

(以下，『16年の工事』と呼ぶ）が創建以来初めて行わ れたことは確実である。

当時, 11 ヶ 月という期間で, どの程度の施工能力があっ たかということは，この泉布館工事の前年に再築工事が 行わ机た地金局（本局）の記録が参考になろう。地金局 の工事 ${ }^{15}$ は前年の明治 15 年 10 月から同 16 年 11 月まで 
13 ヶ月間で，泉布観のそれより 2 ケ月長い。創建当初 の地金局は煉瓦造, 平屋建（金属板莫か）, 石造円柱を 並べた回廊を持つ建物で，1階平面は泉布観の平面上り やや大きい。再築にあたっては，旧建物を全面的に解体 撤去し, 平面規模拡大のうえ基礎から煉瓦を積み直し, 煉瓦造 2 階建（旧煉瓦も使用) ${ }^{16)}$ ，瓦荤に改めた。1 年あまりの工期でこれほどの大改築が可能であったので あるから，11ヶ月を要した『16年の工事』でもまた相 等の大工事を行い得たはずである。

以上の知見のうえに再び『報告書』をみると, その記 述に泉布館の壁体基礎部分以下はフランス積で，1 階床 面より上部の壁体はオランダ積であったとしている ${ }^{17) 。 ~}$ このように 1 つ建物で工法の異っていることは異例 で, 特に基礎部分と壁体の相違は不自然である。一方 ウォートルス ${ }^{18)}$ は銀座煉瓦街建築では，フランス積を採 用していた ${ }^{19)}$ 。これらのことを考え合わせると，創建時 泉布観の壁体も基礎部分よ同じくフランス積で, 後に基 礎部を残し壁体のみオランダ積みに值された可能性が強 、い。これを補足する資料として, 前節 ( 2 ) (1)の図面の 煉瓦壁体部には, 6 間の古図や現状の開口部とは異なる 位置に開口部が示され, 改造の検討がなされたことを䇲 わせる。つまりこのような図面が残っていること自体が 壁体部分の積み替えを十分に示竣している。

以上の工期と煉瓦壁の状態からして, 泉布観はこの時, すなわち『16年の工事』で，全面的に建て替えに等し い改築工事が行われたと考えるのが最も妥当である。

\section{(2) 西側増築の時期}

宮内庁書寮部所蔵の資料に『明治 22 年地積録・泉布 観其外目録』（以下，『地積録』と呼ぶ）がある。これは 造幣局の用紙に記録されているもので, 同年 1 月の日付 がある。従って泉布観が宮内省に移管されたときに, 造 幣局から提出された書類であることは明らかである。こ こには、泉布観、煉瓦石造 百六坪八夕, 同廊下 石造 七拾四坪九合五夕」とあり，これらの合計は 181.8 坪と なる。これに対して, 明治 3 年閠 10 月（1870年 12 月） 付の『造幣寮諸御普請箇所坪数書概略』 ${ }^{201}$ には 155.75 坪, 『造幣局百年史資料編』の「明治 6 年 9 月現在造幣寮諸 建物一覧表」には150:75 坪とあり；面積は一致しないが， いずれにせよ『地積録』の方が多い。また現状の回廊を のぞいた煉瓦壁軀体の面積を算定すれば 105.1 坪で,『地 積録』のそれとほぼ一致し，西側増築後の 96.8 坪 ${ }^{21} に$ 比べ増加している。従って『地積録』の記録は増築後の ものとしてよく，明治 22 年にはすでに増築されていた ことになる。ところで増築前の軀体平面形状が示されて いる最も新しい資料は明治 19 年 1 月の『大阪実測図』 ${ }^{221}$ である。従って泉布観は明治 19 年から同 22 年の間に増 築されたと考えられ，『16 年の工事』とは別の工事とし なければならない。
よって 2 度の改築工事とは，『16 年の工事』と西側増 築時の工事（明治 22 年頃）とすることができる。

4. 転用材の使用について

『報告書』によれば，現状の泉布観の回榔小屋梁，2 階回廊床組, および北側西室の床組に限って多数の転用 材が発見できるとし，これを『転用材使用図』として 2

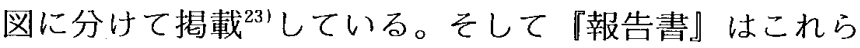
の転用材のほとんどが，かって屋外に使用されていたパ ラペット部の笠木材や地覆材，および蛇腹材であること から，『増築後の泉布観』に改築される前の状態 (創建時) は木造のパラペット・蛇腹を使用した内樋形式の建物で あったとしている。これらの転用材使用図は縮尺的にも 正確に描かれている上思われるので，図から転用材の長 さを求めれば，ほとんど総てが $3 \mathrm{~m}$ をはるかに越え 3.4 $\mathrm{m}$ 内外の長さに算定できる。このことは転用材の元の 使用状態が， $3 \mathrm{~m}$ スパンで 6 間のものではなく, $3.5 \mathrm{~m}^{24}$ スパンで 5 間の時期に使用されていたことを端的に示竣 している。(写真 6 )

ここまでの論証の結果を取りまとめると以下のごとく である。

創建時の泉布観の南北の柱間は 6 間構成であったが, 明治 16 年の工事で，6間の基礎が取り払らわれ，南北 の柱間は対応する 5 間構成に改築された。その後明治 22 年頃に西側に部屋を增築する際，北側の柱問は拡張 され現状の姿になった。このような南北の柱間の変化に 伴い立面形状も変化したはずである。すなわち， 5 間に 改築された時, 当初 6 間のパラペット材・蛇腹材等はそ の長さが不足するため再使用は不可能となり，新材が使 用された。また 22 年頃の西側増築の際, 屋根形状が内 樋から外樋に変更, かつ北側の柱間が拡張されたため, 16 年の工事で新調されたパラペット材. 蛇腹材（特に 北側）は不必要になり取り払われた。この工事で屋根を

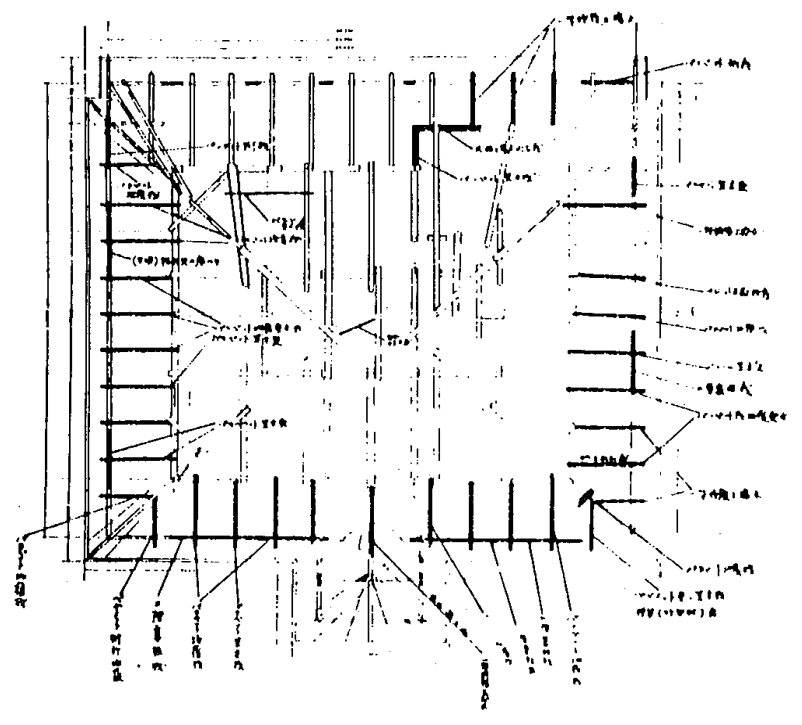

写真 6 小屋組転用材使用図（『報告書』より） 
外樋に変更するためには，現使用中の迴廊小屋梁では長 さが不足するため，不必要になったパラペット材・蛇腹 材がこの工事で回廊小屋・2 階廻廊・北側西室に再使用 されたのが、『報告書』にみる『転用材』とするのが最 も妥当である。

\section{IV. 立面状態の検討}

先の II 章で『報告書』による創建時の復原を示した。 これらの内ニ，ホについても，平面状態と同様に検討す る必要がある。その方法として，ウォートルスによって 同時期に寮内に建築された他の建物図面 ${ }^{25}$ と比較しなが ら論を進める。

\section{1. ウォートルスの意匠の特徵}

ここで比較のため取り上げる建物とは，泉布観（A) と同様にウォートルスの設計・監督になる鋳造場 $(\mathrm{B})$ ・ 地金局 $(\mathrm{C}) \cdot$ 上等異人館 $(\mathrm{D}) \cdot$ 中等異人館 $(\mathrm{E})$ で, 明治 4 年 2 月の創業式にはいずれも竣工していたもので ある。いま各建物に共通すると思われる形式を列挙すれ
ば次のとおりである。(写真 7 11)

(1)回廊の使用, $\mathrm{A} \cdot \mathrm{B} \cdot \mathrm{C} \cdot \mathrm{D} \cdot \mathrm{E}$ は共にコロニアル 様式で，煉瓦軀体の回りに吹放ちの列柱が設けられ，B 以外は列柱の柱間は正面 7 間, 両側面 6 間である。

(2)平面計画の画一化, $\mathrm{A} \cdot \mathrm{D} \cdot \mathrm{E}$ の平面形状は特に酷 似しており，規模もほぼ一致している。玄関より延びる 中廊下は裏面まで達し裹入口となり, この廊下の左右に 部屋を配置した形状である。また 2 階の部屋割も 1 階に 準ずる。

(3)寄棟屋根の使用, $\mathrm{A} \cdot \mathrm{C} \cdot \mathrm{D} \cdot \mathrm{E}$ の屋根形状は類似 しており，煙突の位置まで一致している。

(4)パラペットの使用，これは 5 棟の総てに採用されて いる。B・C・D は石造，Eは趈廊が木造であることか ら恐らく木造であろう。

(5)㲅意匠の統一 $\mathrm{A} ・ \mathrm{C} ・ \mathrm{D} ・ \mathrm{E}$ の葖はそのガラス戸・ ガラリ戸の意匠が特に酷似している。Bについてもほ ぼ同形式のものである。

(6)タスカン様式の使用, E (判 断不能）を除く他の総てに使用さ れている。

以上のように，これらの建物は 統一された意匠を持ち, 特に A ・ $\mathrm{C} \cdot \mathrm{D} \cdot \mathrm{E}$ は類似している。従っ て,これらの建物は個々別々に計 画されたものではなく，一つの基 本設計のもとに，事務所・宿舎・ 応接所の用途に合せて具体的に設 計された可能性が強い。
写真 7 鋳造場正面図

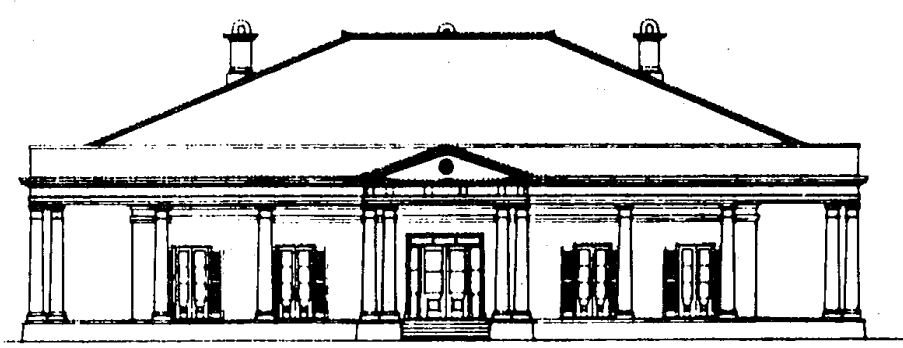

写真 8 地金局正面図

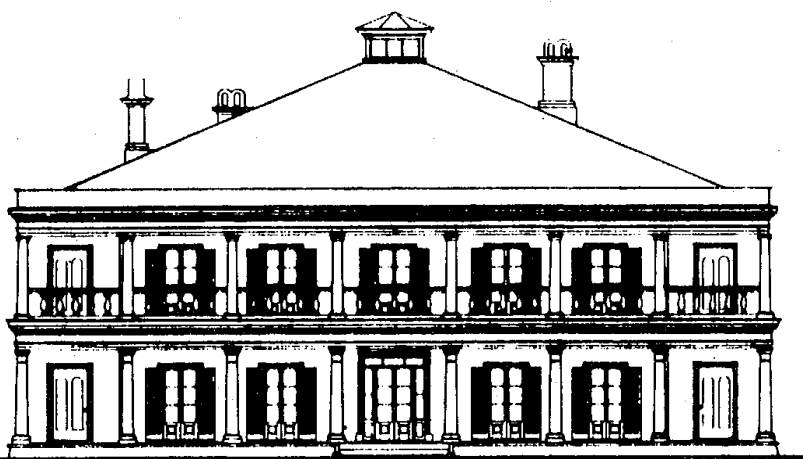

写真 9 上等異人館正面図

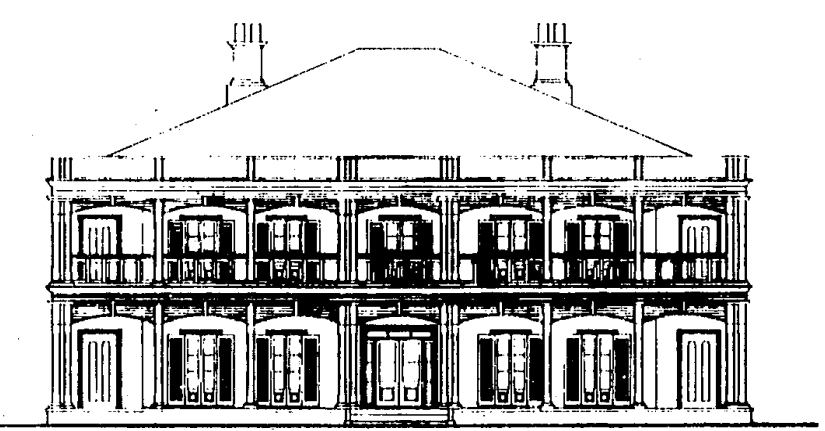

写真 10 中等異人館正面図

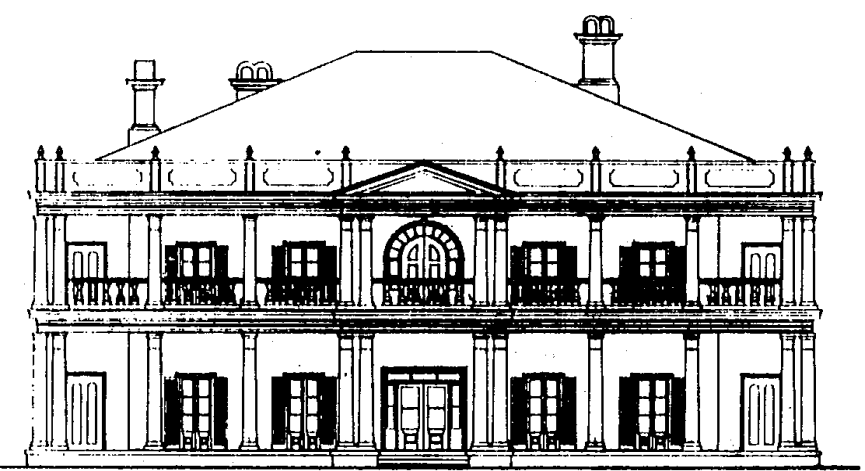

写真 11 泉布観東正面図（中村論文より） 


\section{2. 寮内建物の小屋組と泉布観の小屋組}

ここでは寮内の建物の小屋組に着目して, 泉布観の小 屋組を検討しようとするものである。まずその方法とし て, 前説と同様にすでに判明している創業期の建物の小 屋組を比較し, 次に『報告書』が和小屋とした理由を示す。

(1) 創業期の主要建物の小屋組

(1)鋳造場の本屋, 創業当初は寄棟屋根が 3 連結した形 状で，小屋組は明らかにキングポストの洋小屋で，角材 が使用されている。

(2)鋳造場正面玄関，小屋の中心部に和小屋手法の貫が 見られるが, 全体として合掌・方杖を持ち, 明らかに洋 小屋である。

(3)中等異人館，小屋組の継手部分は鋳造場に比べ不完 全で，梁は丸太で，小屋貫状の材が一部に使用されてい るが，合掌・方杖が明瞭に記入されており，洋小屋であ る。

(4)地金局，断面図には小屋組の一部しか表示されてい ないが, 合掌・方杖が明瞭にみられ, 洋小屋である。中 等異人館之同様に，継手部分は不完全である。

(5)泉布館の附属小屋, この建物は創建当初, 煮炊所・ コック部屋として建築されたもので, 明らかにキングボ ストの洋小屋である。

(6)分析所 ${ }^{26)}$ ，首長キンドル ${ }^{27)}$ の指導による最初のもの で, ウォートルスからキンドルに営繥の主導権がうつっ た頃の建物で，洋小屋である。

(7)銅貨幣鋳造場28), 分析所についで建設された建物で, キンドルの代表的作品でもある。これも明らかに洋小屋 である。

(8)硫酸製造所, 設計者は不明であるが, 明治 6 年竣工 の建物で洋小屋である。

この他, 創業後の建物のほとんよ゙は大小を問わず洋小 屋を持っていたようである。

以上のように，ウォートルスが設計・監督した寮内の 主要建物は知られる限り, 洋小屋, あるいは洋小屋の要 素が見られ，キンドル時代に入ってからもほとんどが洋 小屋であった。このことは，前節でみた意匠面のみなら ず，構造面でも同一に計画された可能性が強い。

（2）泉布観小屋組

先に触れたごとく, 『報告書』は現状の泉布観の小屋 組が和小屋で, 創建時も和小屋であったとしている。『報 告書』が和小屋と推定した理由は定かに示されてはいな いが,「第 2 節, 後世の修補並に形式変更調查」に間接 的に表現されている。次にその一部を示す。

(1)『本屋より引通している垂木は第 2 母屋より $20 \mathrm{~cm}$ 突出した位置で立水切断で終っており，第 3 母屋より軒 先迄引通している垂木は後補材で洋釘打ちである。尚前 記の当初垂木の小口には和釘が斜下方に向って打ち込ま れている。』
(2)『第 4 章 発見物』の『1, 創建時亡判断できる記載』 に『イ, 小屋組，2 階梁大材に丸囲いに司字の焼印』之 ある。

ここであえて推測すれば,『和釗』を使用していること， 『同』字の焼印があることを根拠として創建時から和小 屋であったと判断を下したものと思われる。これらは解 体修理の結果判明した事実であって，これを軽々に動か すことはできない。

ところで『報告書』は『5 間の泉布観』を持って創建 時とし，その間ただ 1 度の改築工事があったとしている が，前章までにみたごとく，泉布観は創建以来明治 16 年と同 22 年頃の 2 度にわたり增改築を受けている。そ の内 16 年のものは全面改築ともいえるほどの大工事で, この年の前後は寮内の他の建物もまた修理を受けた時期 でもある。『報告書』が当初とする和小屋は，実はこの 時期のものとしても説明がつく。その理由は次のとおり である。

(1) 16 年当時和釷の使用はなお一般的291で，小屋組の 小口にそれが打たれていても必ずしも不思議ではない。

(2)『司』字の焼印は確かに明治初年のものである。し かしこれが打たれていた『大材』は創建当初の梁材で， 16 年に和小屋に改築され際に転用された之も考えられ る。ここにこれら『大材』は煉瓦軀体上に使用されてい たもので, 回廊部分に比し憋朽し難い場所であったこと を考慮しなければならない。なお焼印の打たれていたの は梁材のみ年であって, 現在の小屋組を構成する他の部 分 (小屋束等) に打たれていないことは，この推測をよ り確実にするものであろう。

ともあ机『16 年の工事』以前, 小屋組が和小屋であっ たと必ずしも断定することはできず，むしろ泉布観創建 之同期の他のほとんどの建物が洋小屋を採用していた中 にあって，独り泉布観のみを例外亡することの方がより 不自然である。

\section{3. 屋根葺き材料, 軒・胴蛇腹について}

『報告書』は, 現状の泉布館の軒・胴蛇腹は木造で, かつ修理工事時に発見した転用材パラペット材・蛇腹材 であることから，創建時も木造であったとしている。し かしこれらの転用材のほとんどが，前章にみたごとく， $3.5 \mathrm{~m}$ 近くの材である亡いう事実は，『5 間の泉布観』 の時期に使用されていた材で, 創建当初の『6 間の泉布 観』に使用されていたものでないことを自ずから証明し ている。

ところで，前揭のウォートルスが設計した鋳造場・地 金局・上等異人館は石造の柱・蛇腹（中等異人館のみは 柱・蛇腹とも木造）を持っていること，および泉布館は 創建後 2 度の土事が行われていたことを考え合わせれ ば,造幣寮の他の創業期の建物同様,これらが石造であっ た可能性も十分に考えられる。 
また『報告書』は屋根蕞き材料について『軒先瓦の考 証について, 工事中の态急用水（防火, 清掃）溜柝設備 のため, 東側空地を $4 \mathrm{~m}$ 角深 $1.5 \mathrm{~m}$ 堀ると, 現使用の 古式な栈瓦と規格が合致する軒先瓦が 12 枚出土した。 巴文，唐草文共江戸末期明治初の様式に合致している。 として，創建時を瓦草としている。

しかし一般に栈瓦の様式で僅々 10 数年の前後関係を 論じることは説得性に欠け，この場合『汇戸末期明治初』 亡される様式のものが 16 年当時なお使用されていたと してもそれほど不思議ではない。むしろ泉布観と同期の 鋳造場・地金局等が金属板葺 ${ }^{31}$ (鉄板にペイント塗か) であった形跡が濃厚であることから，泉布館もまた鉄板 で草かれていた可能性が強い。

\section{V. 結語}

以上の工事経過を取りまとめると次のとおりである。

(1)創建泉布観の南北柱廊は互いに対応する位置に 7 本 の柱を配した列柱を持つ『6間の泉布観』であった。

(2)明治 16 年に改築工事が行われ，南北の柱間は対応 する『5 間の泉布観』になった。そのため当初のパラペッ 卜材・蛇腹材は使用不可能となり取り払われた。

(3)明治 22 年頃に西側の増築工事が行われた際, 北側 柱廊の柱間が拡張され現状にみる『増築後の泉布観』と なった。この増築工事で軒が外樋形式に改築されたため, 『5 間の泉布観』に使用されていた木造のパラペット材・ 蛇腹材が廻廊小屋梁等に転用して使用された。

このように考えれば，創建時の泉布観の立面が瓦草き 和小屋で，蛇腹材およびパラペット材が木造であったと は断定できず，それはむしろ『16 年の工事』で改築さ れたもので，以前は他の同期の建物との比較から，金属 板菖き洋小屋で，蛇腹及びパラペット材は石造であった とすべきであろう。

1）林野全孝：『造幣局の沿革上建築遺構』建築史研究 29 号, 1961 年 3 月,

菊池重郎：『英人 $\mathrm{T}, \mathrm{J}$, ウオートルスの事蹟に関する研究, その 1』日本建築学会学術講演梗概集, 昭和 49 年 10 月, 『その 2 その 4 論文報告集, 50 年 2 月 51 年 5 月 同, 『鉄の柱とウオートルス】明治村通信 27 号 -32 号, 炤和 47 年 -48 年,

中村角之助：『造幣寮について』建築之社会, 昭和 7 年 8 月号

重要文化財『泉布観修理工事報告書』大阪市教育委員会, 炤和 39 年 3 月,

2) 明治 5 年 12 月 3 日を以て明治 6 年 1 月 1 日に改暦され た。本稿のほとんどはこの日付以降であるため，問題は ないが，陰澘で示す場合は特に西暦をも併記しておく。

3）拙稿『造幣寮の建築——創業期の建築概要——大会学 術講演梗概集・昭和 54 年 9 月，なお鋳造場については拙 稿『造幣寮金銀貨幣鋳造場の当初計画』日本建築学会論 文報告集 317 号・昭和 57 年 7 月，地金局については拙稿
『造幣寮の建築——造幣寮 (本局)について—』日本 建築学会近畿支部研究報告, 昭和 57 年 6 月。

4）鋳造場は昭和 2 年に取り壞わされ，その玄関部分が現在 桜宮公会堂の玄関に転用されている。重要文化財。

5）注 1 ）林野論文参照。

6)『報告書』の『第二説 後世の修補並びに形式変更調査』(24 一 29ページ) の『第五章 考察』に詳述されている。

7）ここにイ、口，八とあるのは，『報告書』では $1 ， 2 ， 3$ 上 番号が付されている。それ以外は『報告書』の原文をそ のまま記載した。

8）大阪造幣局蔵書 $(997,2-24)$ ，明治天皇が明治 10 年 1 月 24 日から大和並び京都へ行幸された時の関係先と準備・ 打合せの文書で，泉布観行在中の日誌等が経られている。 その中に本図面がある。なお，天皇は 2 月 14 日に泉布観 に御到着され，2月16日御出発された。

9）詳しくは注 1) 林野論文に紹介されている。

10）当時，中村氏は造幣局の営縉係長であった

11）詳しくは『金銀貨幣鋳造場出来形絵図』と題されたもので, 『出来形絵図』については拙稿『造幣寮の建築・金銀貨幣 鋳造場の計画について』昭和 55 年 6 月近畿支部研究報告。

12) Napoleun Mancini， 1870 年 3 月 28 日雇入，1877 年 3 月 30 日解雇，イタリア人，延金局助投兼機械方，なお，本 図は造幣博物館所蔵,

13）造幣局蔵『創業初期の建物及び設備の図面及び建物一覧 表』亡題された図面の中に本図が経じられている。

14）明治 5 年造幣寮首長キンドルによって英文の年報書が提 出され，これを翻訳して『日本国造幣首長第 1 号年報書』 として刊行されたのがこの種の報告書の最初で, それ以 後『造幣権頭年報書』となり，さらにここにみる、『造幣 局年報書』となった。そのため『十年報書』とは 10 回め の報告書の意味である。

15）注 3 ）拙稿『造幣寮（本局）について』参照。

16）図面の仕様書きに『古煉瓦』等の文字が多数ある。

17）これ以外に，『報告書』は明らかに後補とみられる西側増 築部分及び空上部の補修部分はイギリス積であったとし ている。

18）ウオートルス（Thomas James Waters）の経歴について は，注 1 ) の菊池論文に詳しい。

19）東京都公文畫館所蔵のウオートルス自筆の銀座煉瓦街の 図（彩色）には明膫にフランス積が示されている。

20）大隅文書 A 2138，この文書には『曲尺 6 尺方 $\Rightarrow$ 以 1 坪卜 又総テ外法习執尺ス』とあり，当時建物がある程度完成 していたことを示している。なお，これは営䋨司の報告 である。

21）この数值は，当研究室で作成した創建平面図をもとに計 算したもので, $61.6 \times 51.7 / 36+7 \times(10.2+23.5+9.3)$ $/ 36=96.8$ (単位は尺) と計算できる。

22）注 1) 林野論文に掲載がある。

23）『報告書』31 から32 ページに『転用材使用図』として, 『小 屋伏図』・『二階床梁伏図』の 2 図が揭載されている。

24）6間構成の場合，南北の柱真々の間隔は 9.6 尺（約 $3 \mathrm{~m}$ ) で, 5 間の場合は 11.5 尺（約 $3.5 \mathrm{~m}$ ) となる。転用材の中 には $3 \mathrm{~m}$ 近くのものも報告されているが，これは東側正 面（10尺）に使用されていたと考えられる。

25）ここで比較のため使用した図面とは，Aにあっては現状 と『報告書」揭載図, $\mathrm{B}$ は『出来形絵図」, C は注 1 ) 中 
村論文揭載図 · 三井文庫所蔵図， D は C 上同断，E は中 村論文によった。

26）分析所については拙稿『分析所について』昭和 57 年 10 月大会学術公演梗概集

27) Thomas William Kinder，イギリス人造幣局首長，1870 年 2 月 2 日雇傭, 1875 年 1 月 31 日解雇, キンドルにつ いては造幣局の局史が詳しい。

28）銅貨幣鋳造所については拙稿『銅貨幣鋳造場よキンドル』 56 年 6 月近畿支部研究報告。
29）村松貞次郎：『日本近代建築技術史』（昭和 51 年 9 月，彰 国社刊）による。

30）当時の工事主任補佳，高橋析氏の教示による。

31）三井文庫『造幣寮御入用勘定書』等に『屋根用丁銅』『鉄 板屋根用』『屋根鉄板』等亡記載があるが，使用場所が明 示されていないため，その建物を限定しえない。またウ オートルスの銀座煉瓦街の図面にも金属板莫に示されて いる。

\title{
SYNOPSIS
}

UDC : $72.036: 725.4: 728.54$

\section{THE BUILDING OF IMPERIAL MINT RECONSIDERATION OF SENPUKAN}

\author{
by TOSHIO KIMURA, Assistant Kansai Univ. \\ and Dr. KOICHI YAMADA, Prof. Kansai Univ., \\ Members of A. I. J.
}

It is wellknown that Imperial Mint Osaka was the first factory in Japan having been constructed when Japan first opened its door to foreign countries Meiji Era, and there were various studies made by many scholars about it.

The Opening Ceremony of the Mint was held on April in 1871, and at that time, the Coining Factory, the Main Office, the Foreigner Residence and the SENPUKAN, which were principal buildings of the Mint, have been completed. But most of the original buildings of the Mint were pulled down; and now, survivals are only the SENPUKAN and a part of the Coining Factory.

The repair works of the SENPUKAN which had been constructed for the guest-house of the Mint were finished in 1964, and repair report was published with careful analyis about one, still it seems to have some unsolved problems. In this report, first we will examine the plan of the SENPUKAN and next will examine the elevation which would be changed according to the plan. 